DOI: https://doi.org/10.33989/2075-146x.2021.27.247058

УДК 373.5.046-024.71:[37.015.3:57]

\title{
ІРИНА ЗАЙЦЕВА
}

ORCID 0000-0001-5789-7240

\section{ТЕТЯНА ЮСИПІВА}

ORCID 0000-0001-5865-9500

Дніпровський національний університет імені Олеся Гончара, м. Дніпро

\section{ГАЛИНА М'ЯСОїД}

ORCID 0000-0001-7781-7535

Університет імені Альфреда Нобеля, м. Дніпро

\section{НАВЧАЛЬНА МОТИВАЦІЯ УЧНІВ ДО ВИВЧЕННЯ БІОЛОГІЇ У СЕРЕДНІЙ ЗАГАЛЬНООСВІТНІЙ ШКОЛІ ТА ЛІЦЕЇ БІОЛОГІЧНОГО ПРОФІЛЮ}

\begin{abstract}
У статті розглянуто питання навчальної мотивації, зокрема мотивації до навчання біології у загальноосвітньому та профільному закладах середньої освіти. За методикою О. Окунєвої, Л. Васильєвої виявлено рівень розвитку мотивації навчання, тип мотивації і показник мотивації, як показник досягнення успіху та уникнення невдач, проаналізовано фактори впливу на навчання учнів. Доведено, що навчання у профільному закладі середньої освіти ефективніше спрямовує учнів на досягнення поставленої мети в навчанні, допомагає зорієнтуватися під час вибору майбутньої професії. В результаті опитування визначені організаційні форми навчання та типи завдань, які слід використовувати у навчальному процесі 3 метою підсилення навчальної мотивації старшокласників.
\end{abstract}

Ключові слова: навчальна мотивачія, методика вивчення мотивації, діагностика, анкетування, опитування, заклади середньої освіти, біологія

Постановка проблеми. Значущість розробки проблеми мотивації, іiї формування та зміни пов’язана 3 аналізом джерел активності людини, спонукальних сил ії діяльності та поведінки. У процесі становлення особистості у підлітковому віці відбувається періодична зміна провідних видів діяльності та спілкування. При цьому різні види спілкування забезпечують розвиток переважно споживчо-мотиваційної сфери особистості, тоді як провідні види діяльності, передусім навчальної, сприяють становленню пізнавальної сфери психіки. Дослідження мотиваційних рушійних сил, спрямованих на становлення пізнавальних процесів і розвиток особистості, та основних предикторів, що впливають на ці процеси, $є$ важливою психолого-педагогічною проблемою. Особливу увагу в цьому аспекті слід звернути на виокремлення такого чинника, як ефективність впливу освітнього середовища закладу середньої освіти на особистісний розвиток та мотивацію до навчальної діяльності учнів. Найбільшої актуальності питання сформованості навчальної мотивації набуває у старшій та, особливо, спеціалізованій школі, оскільки профільне навчання потребує стійкого пізнавального інтересу та навчальної активності учнів, перших серйозних кроків у визначенні майбутньої професії.

Аналіз останніх досліджень і публікацій. Мотивація як проблема психолого-педагогічних досліджень привертає увагу багатьох вчених. Більшість науковців сходиться на думці, що є дві сторони мотивації: динамічна (енергетична) і змістовно-смислова, які виступають як єдине ціле. В. М. Мясищев розробляв цей принцип єдності в системі відносин людини, О. К. Леонтьєв - у співвідношенні змісту і значення, С. Рубінштейн досліджував його як інтеграцію спонукань та їх смисловий контекст, Л. Божович, В. Чудновський вивчали єдність спрямованості особистості та динаміки їі поведінки, П. Гальперін досліджував орієнтування в діяльності.

А. Дербеньова зазначає, що мотивація - це система факторів, що викликають активність організму і визначають спрямованість поведінки людини (Дербеньова, 2012, с. 7). Потреби, мотиви, цілі є основними складовими мотиваційної сфери людини. О. Леонтьєв відзначав, що потреба сама по собі не може бути мотивом поведінки, оскільки вона здатна породити лише ненаправлену активність організму, а спрямованість і організованість поведінки забезпечується лише мотивом як предметом даної потреби (Леонтьев, 2002, с. 38). Мотив $є$ стійкою особистісною властивістю, що зсередини спонукає особу до здійснення певних дій. Усвідомленим мотивам належить провідна роль у формуванні спрямованості особистості.

Вивчаючи навчальну мотивацію, Л. Божович виділила широкі соціальні мотиви отримання знань і мотиви, породжені самою навчальною діяльністю. Дослідниця розуміє під поняттям «мотив» те, заради чого здійснюється діяльність на відміну від мети, на яку ця діяльність спрямована. По суті, до мотивів належить все, 
що спонукає активність дитини, зокрема прийняття нею рішення, почуття обов'язку, усвідомлення необхідності. Тому, даючи характеристику мотивів навчальної діяльності школярів, Л. Божович називає мотивами всі збудники цієї діяльності (Божович, 2001, с. 120).

А. Дербеньова наголошує на необхідності визначити, які мотиви навчальної діяльності є зовнішніми, а які - внутрішніми (Дербеньова, 2012, с. 17). Мотив $є$ внутрішнім, якщо він збігається з метою діяльності, а за умов навчальної діяльності опанування змісту навчального предмета є водночас і мотивом, і метою. Психологи зазначають, що внутрішні мотиви до навчання створюють ситуацію, коли учень отримує від процесу навчання задоволення і досягає свої цілей. Якщо внутрішня мотивація є домінуючою, учень проявляє більшу пізнавальну активність.

Проте, як засвідчує практика, значний вплив на формування мотивації до вивчення біології здійснюють і зовнішні мотиви, зокрема, необхідність виконання тестових завдань, зовнішнього незалежного тестування. Аналізуючи ситуацію, В. Карандій зазначив, що у 2018 році поріг із біології не здолали тільки $8 \%$, в той час як у минулому році - 13\% абітурієнтів, але разом з тим біологію стали менше обирати. Однією 3 причин могло бути рішення Міністерства охорони здоров'я про встановлення порогу у 150 балів для вступу на медичні спеціальності, внаслідок чого учні, які не мали впевненості у своїх знаннях із біології, відмовились від вступу на ці спеціальності (Карандій, 2018).

Посиленню навчальної мотивації школярів до вивчення біології присвячено багато методичних розробок вчителів, методистів, вчених, які запроваджують різні методи й прийоми навчання. А. Маковецька і О. Цуруль зазначають, що типові навчальні заклади орієнтовані переважно на підтримування зовнішньої мотивації у вигляді контролю, наказів і вимог, що згубно позначається на внутрішній мотивації і веде до поступового зниження інтересу учнів до навчання (Маковецька, 2015, с. 55). Натомість у профільній старшій школі, зокрема природничого напряму, мають бути створені умови для застосування інноваційних форм і методів навчання, формування в учнів свідомої мотивації навчально-пізнавальної діяльності, що сприяє розвитку здібностей і обдарувань учнів, потреби й уміння їх до самовдосконалення, оволодіння певним рівнем майбутньої професійної підготовки (Загальна методика..., 2006, с. 538).

Метою дослідження $є$ порівняльне вивчення мотивації учнів до вивчення біології у середній загальноосвітній школі та в ліцеї біологічного профілю.

Виклад основного матеріалу. Для проведення досліджень обрали заклади середньої освіти у м. Дніпро: КЗО СЗШ № 52 - типову загальноосвітню середню школу, яка не має спеціалізації з біології, але має інформаційно-технологічний напрям навчання, та КЗО «Дніпропетровський обласний медичний ліцей-інтернат «Дніпро» (далі - ДОМЛІ «Дніпро»), що є профільним навчальним закладом середньої освіти 3 посиленим вивченням біології. Вивчення навчальної мотивації виконувалось в межах дипломного дослідження Колєснєвої А.В. «Вивчення мотивації навчання біології учнів середньої загальноосвітньої школи та ліцею біологічного профілю» під керівництвом проф. Зайцевої І.О. Дослідження рівнів сформованості навчальної мотивації учнів старших класів до вивчення біології здійснювалося шляхом вибіркового опитування (анкетування). Анкетування відбувалося дистанційно, шляхом заповнення учнями опитувальника, створеного у Google-формі, на який учні отримали посилання. У дослідженні взяли участь 32 учні 11 і 10-го класів КЗО СЗШ № 52 та 52 учні 9, 10 та 11-го класів ДОМЛІ «Дніпро» (рис. 1).

Анкетування проводили одночасно з усіма учасниками дослідження, наприкінці навчального року, коли учням повідомили попередні підсумкові оцінки і вони мали сформовані оріснтації щодо подальшого навчання. Таким чином, до початку заповнення опитувальника, учні отримали посилання на анкету, інструкцію та, за необхідності, роз'яснення вчителя щодо мети дослідження.

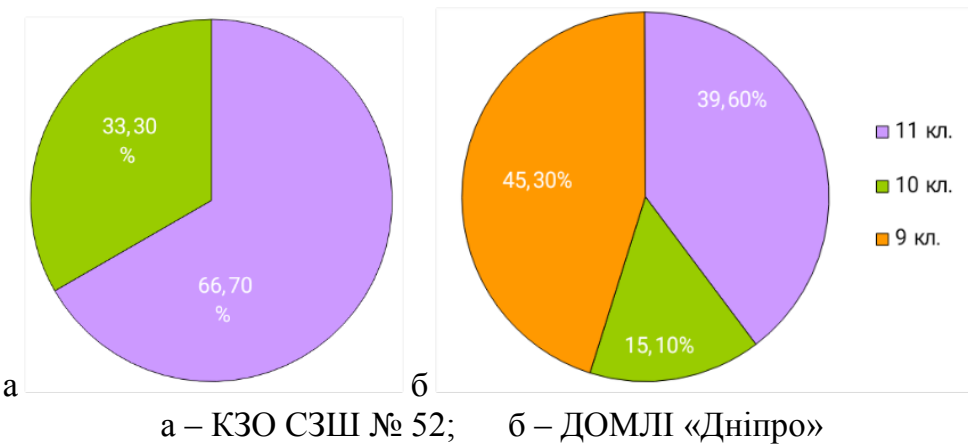

Рис. 1. Розподіл респондентів досліджуваних закладів освіти за класами

3 метою проведення порівняльного аналізу результатів по двох закладах, було створено дві ідентичні за змістом та структурою анкети (Мотивація до навчання, 2020). Відповідно до вимог розроблена анкета містить (Структура анкети, 2019): вступну частину (хто і для чого проводить опитування; інструкція щодо заповнення анкети; гарантії анонімності; орієнтовна тривалість; подяка за участь); основну змістовну частину; соціальнодемографічний блок (паспорт). В основній частині представлено 9 питань (за методикою О. Ю. Окунєвої і 
Л. А. Васильєвої «Методика вивчення мотивації навчання підлітків» (Окунева, Васильева, 2007) та три питання, спрямовані на з'ясування мотивацій до навчання біології. Два останніх питання складали «паспорт» (заклад освіти, клас, в якому навчається респондент).

Питання анкети складені таким чином, аби виявити рівень мотивації навчання, тип мотивації і показник мотивації, як досягнення успіху та уникнення невдач. Щоб виключити випадковість вибору і отримати більш об'єктивні результати, учням пропонувалося вибрати два варіанти відповідей. Досліджувані мотиви навчальної діяльності розподілені за трьома блоками: особистісний сенс навчання (питання 1-3 анкети), здатність до цілепокладання (питання 4-6) та різні види мотивів (питання 7-9). Кожний варіант відповіді в питаннях виражає визначену кількість балів залежно від того, який саме мотив виявляється у відповіді: зовнішній мотив - 0 балів; ігровий мотив - 1 бал; отримання оцінки - 2 бали; позиційний мотив - 3 бали; соціальний мотив - 4 бали; навчальний мотив - 5 балів. Для підрахунку значень всіх відповідей використовували відносні одиниці (відсотки), а не абсолютні числа, оскільки розмір вибірок у двох закладах освіти був неоднаковим. За сумою балів виділяють такі підсумкові рівні мотивації навчання школярів: I - дуже високий (72-85); II - високий (5571); III - середній (42-54); IV - знижений (30-41); V - низький (до 29). Рівні мотивації за 1-им блоком демонструють, наскільки сильним для школяра є особистісний сенс навчання. Рівні мотивації за 2-им блоком свідчать про здатність до цілепокладання. Третій блок анкети виявляє спрямованість мотивації на пізнавальну або соціальну сферу. Для цього підраховували частоту виборів всіх видів мотивів по всій виборці школярів, після чого визначали відсоткове співвідношення між видами мотивів.

За отриманими даними складено таблицю рівнів сформованості трьох блоків параметрів, де наведено відсоток відповідей, помножений на абсолютну їх кількість (табл. 1). Отримані результати свідчать, що за усіма блоками мотиваційної структури більш високі бали продемонстрували респонденти профільного закладу освіти ДОМЛІ «Дніпро».

Результати оцінювання сформованості різних блоків мотивів у структурі мотивів навчальної

Таблиця 1 діяльності підлітків, бали

\begin{tabular}{|l|c|c|}
\hline Блок мотивів & КЗО СЗШ № 52 & ДОМЛІ «Дніпро» \\
\hline Блок 1. Особистісний сенс навчання & 2129 & 2244 \\
\hline Блок 2. Здатність до цілепокладання & 2240 & 2504 \\
\hline Блок 3. Різні види мотивів & 1713 & 1949 \\
\hline
\end{tabular}

Аналіз даних за показниками блоків 1 і 2 дозволить вчителеві зробити висновок про ефективність педагогічної діяльності в аспекті формування особистісного сенсу навчання та здатності до цілепокладання, що допоможе вжити, за необхідності, корекційних заходів.

На рис. 2 і 3 представлені результати щодо проаналізованих відповідей (у відсотковому відношенні), які були отримані в ході анкетування у двох закладах освіти.

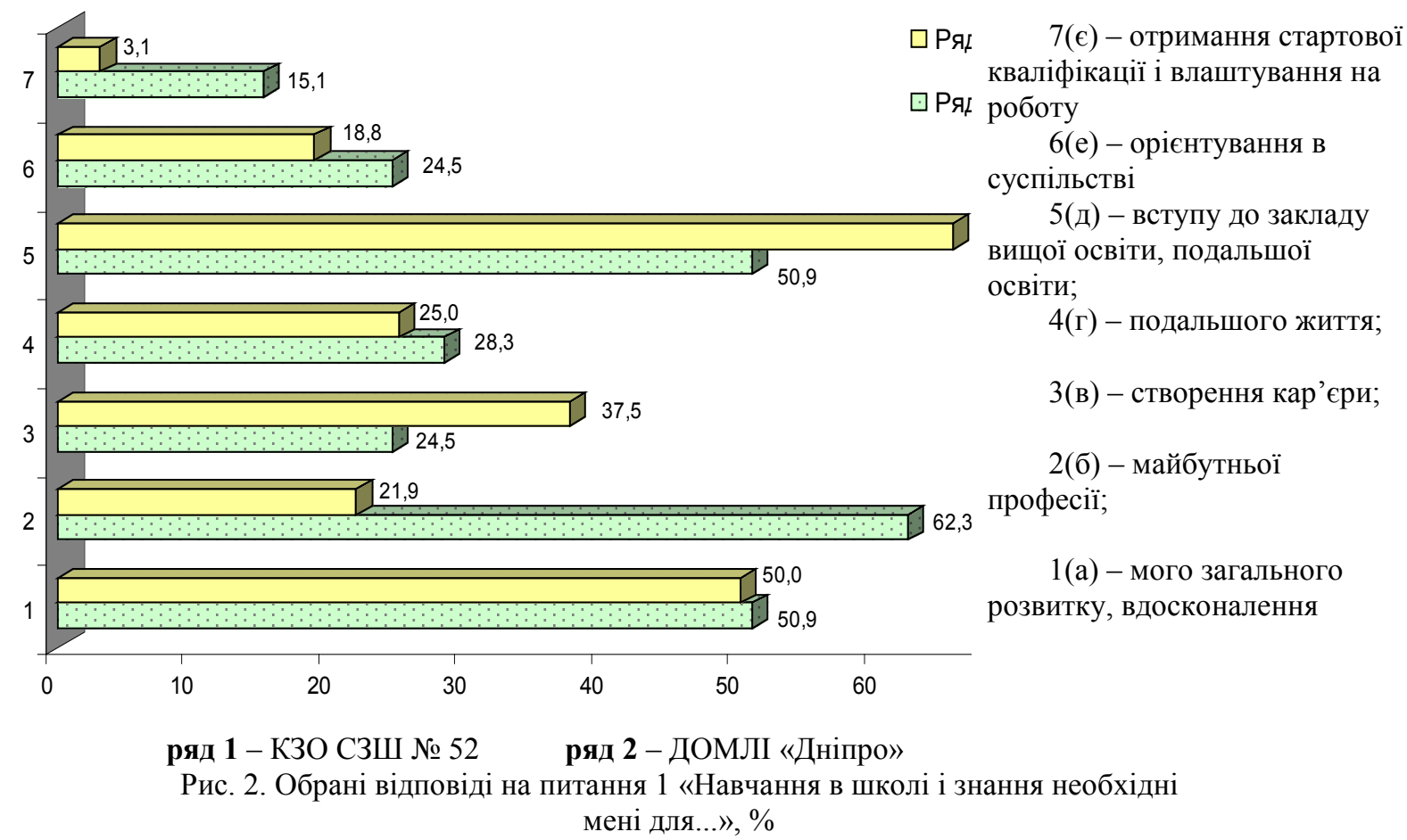


У блоці 1 «Особистісний сенс навчання» для учнів ДОМЛІ «Дніпро» найвищим мотивом (62,3\%, 50,9\%\%) є «вступ до вузу, подальша освіта», «майбутня професія» (питання 1, б, д), що склало сумарно 311,5 балів; другим в рейтингу мотивом $(28,3 \%) є$ сенс навчання для «подальшого життя» - 203,6 балів (питання 1а).

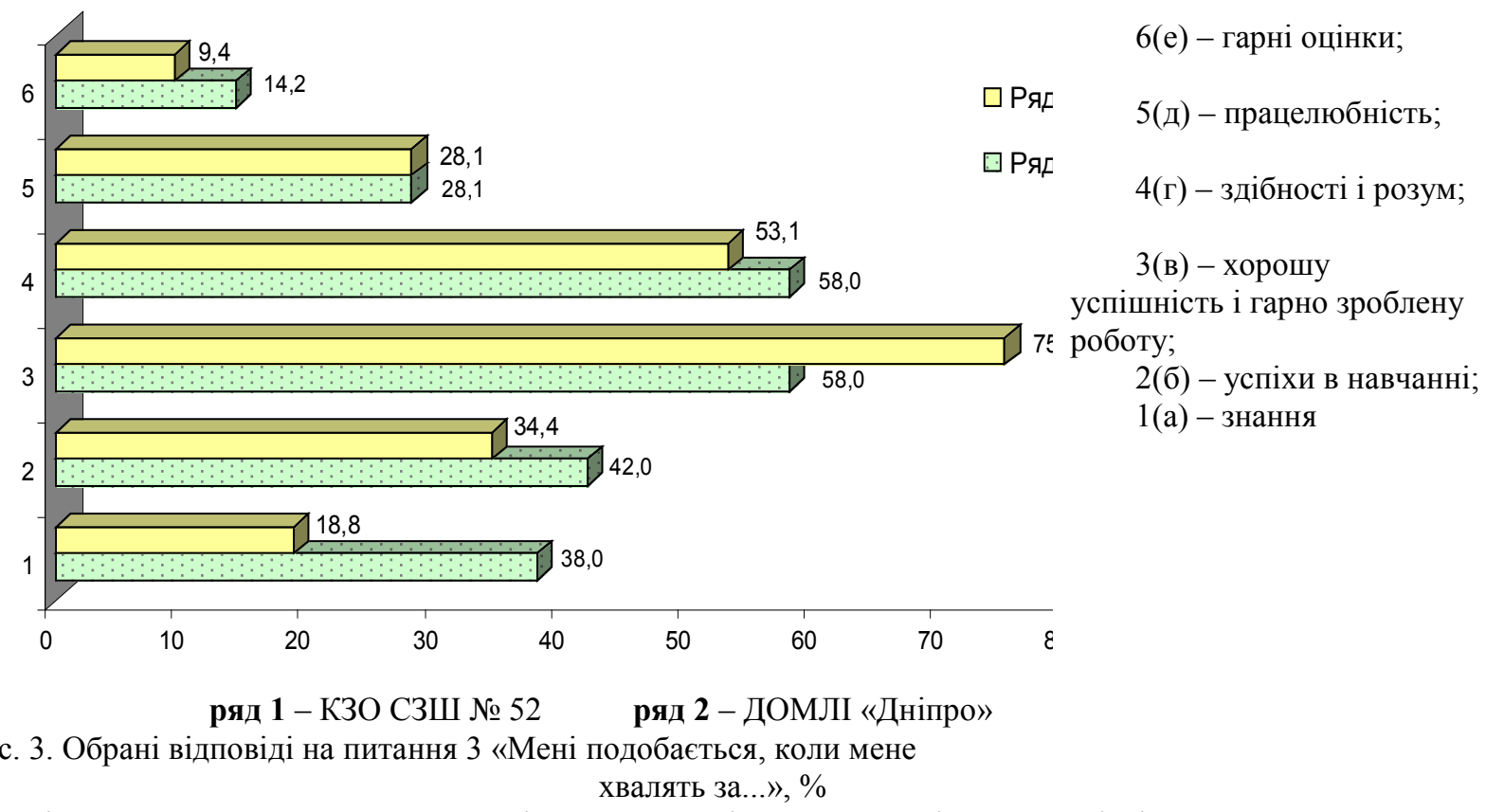

В учнів КЗО СЗШ № 52 мотиви в блоці 1 були дещо іншими. Перші рейтингові місця належать мотивам «відчуваю, що вчитися потрібно» $(53,1 \%)$ - 312,5 балів (питання 2, е) та схвалення за гарну роботу й успішність $(75,0 \%)-225$ балів (питання 3, в). Втім половина учнів в обох навчальних закладах вважає, що навчання в школі i знання необхідні для власного загального розвитку та вдосконалення. Найбільша статистична різниця спостерігається в учнів двох закладів середньої освіти в блоці 2 сформованості здібностей до цілепокладання (рис. 4). Так, для учнів ДОМЛІ «Дніпро» найвищий бал у рейтингу (з частотою 81,1\%) належить мотиву «При плануванні своєї роботи я... а) обмірковую іï» (питання 6, а), тобто планування власних навчальних дій - 405,5 балів. Серед учнів КЗО СЗШ № 52 теж домінує $(78,1 \%)$ мотив планування діяльності, але бал інший - 390,5. Другий за рейтингом мотив в обох закладах (62,3\% та 53,1\% відповідно) 3 однаковими балами в кожній підвибірці - «При плануванні своєї роботи я... в) намагаюсь зробити все старанно» (питання 6, в).

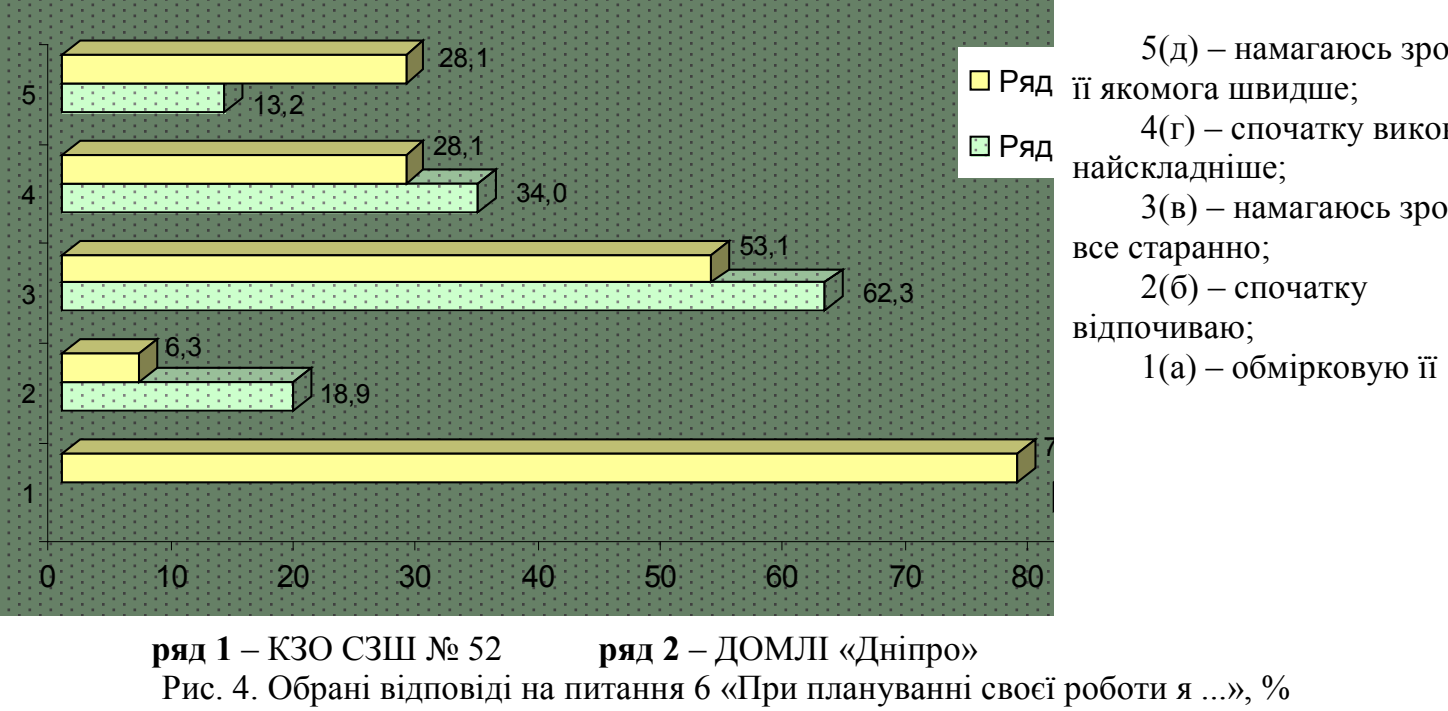

За питаннями блоку 3 виявлено значно вищі бали стосовно мотивації навчальної діяльності учнів ДОМЛІ «Дніпро»: 1949 балів проти 1713 балів в учнів загальноосвітньої середньої школи (рис. 5, 6). Серед ліцеїстів домінує навчальний мотив «Я вивчаю матеріал добросовісно, тому що... б) він мені потрібний» $(86,8 \%)$, який складає 260,4 бали (питання 8, б). Другий у рейтингу учнів ДОМЛІ $є$ мотив «Найцікавіше на уроці... д) діалог, обговорення, дискусія $(49,1 \%)-245,5$ бали (питання 7, д). Можна стверджувати, що вміння проявити свої 
знання, опанувати нові знання за допомогою діалогово-дискусійних форм навчання характерні ліцеїстам набагато більше, ніж учням загальноосвітньої школи, серед мотивів яких переважають відповіді «Я вивчаю матеріал добросовісно, тому що... в) мені потрібна хороша оцінка» $(66,8 \%)$ - 225 балів (питання 8, в), та «Найцікавіше на уроці... в) практика, виконання завдання» $(43,8 \%)$ - 219 балів (питання 7, в).

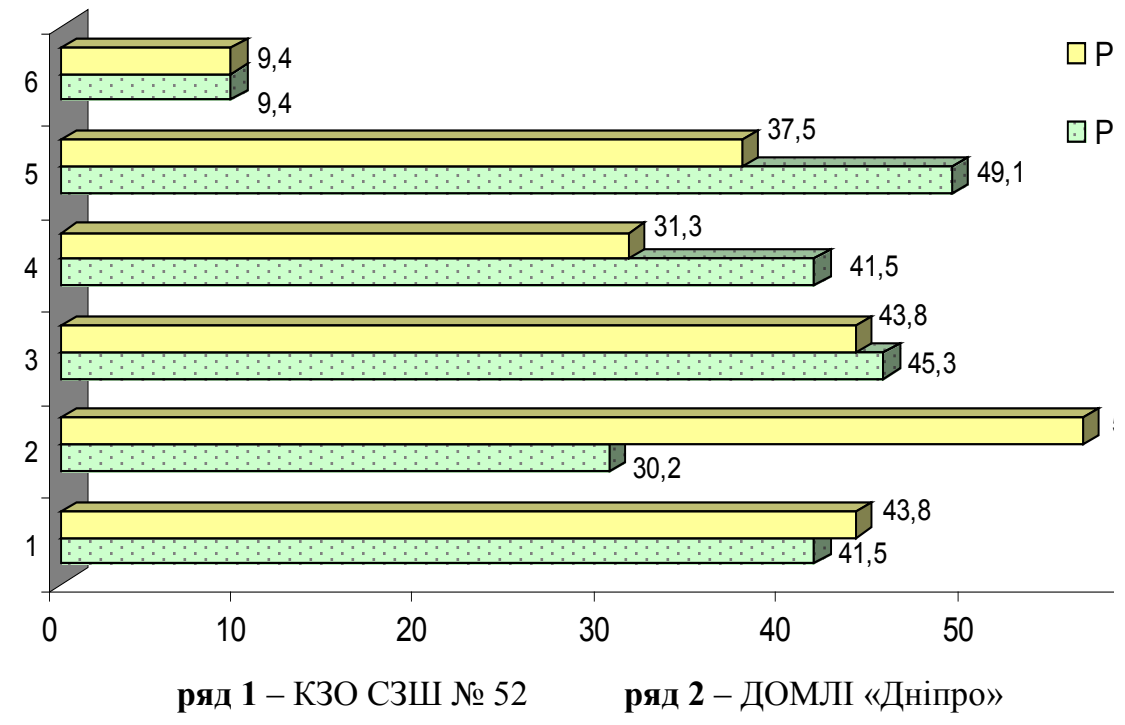

6(е) - спілкування 3 друзями;

P $\quad 5($ д) - діалог, обговорення, дискусія;

4(г) - цікаве повідомлення вчителя;

3(в) - практика, виконання завдання;

2(б) - маловідомі факти;

1(a) - обговорення цікавого мені запитання

Рис. 5. Обрані відповіді на питання 7 «Найцікавіше на уроці ...», \%

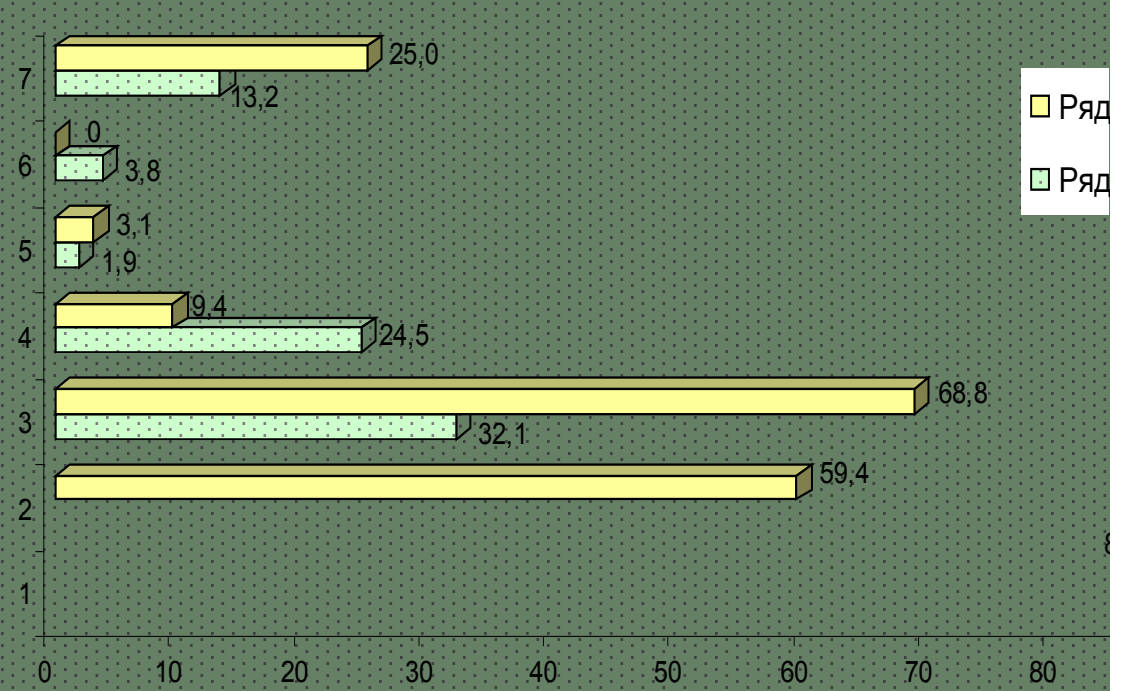

7(є) - якщо в мене гарний настрій;

6(е) - спілкуюся 3 друзями;

5(д) - мене заставляють;

4(г) - стараюсь завжди;

3(в) - мені потрібна хороша оцінка;

2(б) - він мені потрібний;

1(а) - він мені дуже цікавий

ряд 1 - КЗО СЗШ № 52 ряд 2 - ДОМЛІ «Дніпро»

Рис. 6. Обрані відповіді на питання 8 «Я вивчаю матеріал добросовісно тому, що ...», \%

Окремим блоком анкети були представлені питання, метою яких було з'ясувати мотивації старшокласників саме до вивчення біології та виявити фактори впливу на формування такої мотивації. На питання «Які дослідницькі проєкти тобі подобаються більше?» 56,3\% учнів ДОМЛІ «Дніпро» обрали виконання дослідницьких проєктів індивідуально, самостійно, а не в групі, що на 6,3\% більше, ніж в КЗО СЗШ № 52 . Такий результат може свідчити про більш високу індивідуальну спрямованість на навчання, більш сформовані внутрішні стимули, а також більшу впевненість у своїх силах та незалежність від інших членів групи, певну конкуренцію. Однак учні обох шкіл продемонстрували приблизно рівний розподіл думок щодо форм виконання проєктів.

На питання з відкритою відповіддю «Напиши, які завдання на уроці за цей навчальний рік запам’яталися тобі найбільше? 3 якої теми? Чому?» було отримано 34 відповіді від учнів ДОМЛІ «Дніпро», 3 яких 52,9\% так чи інше стосувалися уроків біології, проведення лабораторних робіт з біології, розв’язування біологічних задач, розділів генетики, селекції, біотехнології, адаптацій, здоров'я людини. Високу зацікавленість учні проявили також до лабораторних робіт з хімії (25,5\%). Окремі відповіді стосувалися екології, фізкультури, української мови. Від учнів КЗО СЗШ № 52 на поставлене питання в анкеті було отримано 20 відповідей, із яких 20,0\% 
стосувалися біологічних тем («ланцюги живлення», «цікаві факти з біології», «біологічні проєкти», «біологічні основи здорового способу життя») та екології («проєкт про Чорнобиль»), 20\% - лабораторних робіт 3 хімії, проте у відповідях учнів КЗО СЗШ № 52 простежується більш широкий спектр інших тем і дисциплін тригонометрія, фізика, математика, комбінаторика, історія, алгебра.

Учням було також запропоновано визначити типи завдань, які вони вважають цікавими та готові виконувати в класі, у відповіді на запитання анкети: «Які завдання ти хотів би / хотіла б виконувати на уроках?». Було отримано 30 відповідей учнів ДОМЛІ «Дніпро» та 22 відповіді від учнів КЗО СЗШ № 52. Аналіз отриманих відповідей дозволяє стверджувати, що учні обох шкіл бажали б виконувати «цікаві, практичні» завдання, але учні профільної школи висловлюють і більш конкретні побажання щодо наукових завдань, дослідницьких робіт, дискусій, лабораторних робіт, «завдань які виходять за рамки нинішньої програми, наприклад, вільне обговорювання з вчителем теми», а також «завдань, які пов’язані з лікарською справою».

3 метою усунути фактори демотивації, була здійснена спроба зрозуміти, що може завадити вдома виконувати певні навчальні завдання. Було поставлене питання: «Які завдання ти не любиш виконувати вдома? Чому?» Багато в чому відповіді учнів двох закладів збігаються за змістом - писати конспекти, реферати, робити презентації, вивчати вірші, виконувати не цікаві і не потрібні в майбутньому завдання, завдання із незрозумілою умовою тощо, проте учні ДОМЛІ «Дніпро» надали більш розгорнуті і вмотивовані відповіді: «Творчі завдання, бо у них немає чітко поставленої мети та плану виконання»; «Практичні роботи, але не всі; зокрема ті, які не націлені на виховання в нас практичних компетентностей та формування якихось навичок...»; «Деякі завдання мають характер закріплення, і це добре, але більшість вчителів все ж задають занадто багато однотипних завдань додому». По дві відповіді «Немає таких завдань» було отримано від учнів ДОМЛІ «Дніпро» $(6,0 \%)$ та КЗО СЗШ №52 (13,0\%), відповідь «Всі завдання» - одна (3,0\%) та дві (8,7\%) відповідно.

Слід відзначити й окремі відповіді на питання «Які завдання ти не любиш виконувати вдома? Чому?», які свідчать про різні методичні підходи у досліджуваних закладах освіти. Так, два респонденти з ДОМЛІ «Дніпро» не люблять «розбирати теми, яких ми не проходили, самостійно, бо результат зазвичай поганий», «розбирати нові теми самостійно, бо це повинен робити вчитель», тоді як в КЗО СЗШ № 52 два респонденти відповіли, що не люблять виконувати «лабораторні роботи, вдома немає можливості виконувати досліди», «лабораторні та практичні, бо вдома ти це робиш сам, а не в групі, треба дивитися відео в Інтернеті, і вдома немає обладнання».

Професійні оріснтації старшокласників були проаналізовані за результатами відповідей на питання анкети «Ким ти хочеш стати? (обери або напиши свою відповідь у вільному рядку)». Очевидним є вибір майбутньої професії переважної більшості учнів ДОМЛІ «Дніпро» (75\%), які обрали свій професійний шлях та бажають бути лікарями. Ще 15,1\% респондентів назвали професії, для яких вивчення біології грає визначальну роль: дослідником-біологом, зоологом, кінологом, мікробіологом, вчителем біології. Зовсім інші професійні орієнтації виявлені в учнів старших класів КЗО СЗШ № 52. Значна кількість учнів (15,1\%) ще не визначилися щодо майбутньої професійної діяльності, в той час як у ДОМЛІ «Дніпро»- тільки 3,8\%. Отримані дані свідчать про розпорошеність уявлень учнів щодо свого майбутнього, що є природнім для загальноосвітньої середньої школи, на відміну від учнів профільного закладу середньої освіти.

Висновки. Досліджено явище мотивації та навчальної мотивації учнів загальноосвітньої школи та профільного закладу середньої освіти медичного напряму шляхом анкетування старшокласників 3 використанням методики О. Окунєвої, Л. Васильєвої та додаткових питань щодо мотивації до вивчення біології. Установлено, що за усіма блоками мотиваційної структури спостерігаються більш високі бали у респондентів профільного закладу. Найбільша статистична різниця відзначена в учнів двох закладів в блоці 2 - сформованості здатності до цілепокладання. В учнів профільного закладу визначено більш високу індивідуальну спрямованість на навчання, більш сформовані внутрішні стимули, а також більшу впевненість у своїх силах та незалежність від інших членів групи, визначеність щодо майбутньої професійної діяльності відповідно до профілю закладу середньої освіти.

\section{Список використаних джерел}

Божович, Л. И. (2001). Проблемы формирования личности. Москва; Воронеж: МПСИ: МОДЭК. Дербеньова,А.Г.(2012). Усе про мотивачію. Харків: Основа.

Мороз, І. В. (Ред.). (2006). Загальна методика навчання біологї̈: навчальний посібник для студ. вищих навч. закладів. Київ: Либідь.

Карандій, В. (2018). Не можна макове зернятко виміряти лінійкою з сантиметровою поділкою. Про перші результати 3 НО та плани на майбутнє. Взято $3 \mathrm{https} / / / \mathrm{zn} . u \mathrm{a} / \mathrm{ukr} / \mathrm{EDUCATION/vadim-karandiy-ne-mozhna-makove-zernyatko-}$ vimiryati-liniykoyu-z-santimetrovoyu-podilkoyu-281335_.html

Леонтьев, В. Г. (2002). Психологические механизмы мотивайии учебной деятельности. Новосибирск: Новосибирский полиграфкомбинат.

Маковецька, А.С., Цуруль, О. А. (2015). Формування мотивації до вивчення біології в учнів основної школи. В кн. Педагогіка: традииї̈ та інновації: матеріали II міжнар. наук.-практ. конф. (с. 55-58). Харків: Гельветика.

Мотивачія до навчання. Анкета для старшокласників. https://docs.google.com/forms/d/e/1FAIpQLSfdMMloq_10cINhehDM4d8yV7_IxoKFTxuhH6cYLwhhoCFITw/viewform ?usp=sf_link 
Окунева, Ю. О., Васильева, Л. А. (2007). Методика изучения мотивации учения старшеклассников. Учебный центр федерации интернет-образования. Взято з http://fio.novgorod.ru/projects/project2007/diagnost.htm

Ібрагімова I. М. (Упоряд.). (2019). Структура анкети, типи та види запитань. Вивчення потреб у навчанні та розвитку: посібник. Київ: Проект «Доступна та якісна правова допомога в Україні».

\section{References}

Bozhovich, L. I. (2001). Problemy formirovaniya lichnosti [Problems of personality formation]. Moskva; Voronezh: MPSI Publ.: MODEK Publ [in Russian].

Derbenova, A. H. (2012). Use pro motyvatsiiu [It's all about motivation]. Kharkiv: Osnova Publ. group [in Ukrainian].

Ibrahimova I. M. (Comp.). (2019). Struktura ankety, typy ta vydy zapytan. Vyvchennia potreb u navchanni ta rozvytku [Questionnaire structure, types and kinds of questions. Study of learning and development needs: a guide]: posibnyk. Kyiv: Proekt «Dostupna ta yakisna pravova dopomoha v Ukraini» [in Ukrainian].

Karandii, V. (2018). Ne mozhna makove zerniatko vymiriaty liniikoiu z santymetrovoiu podilkoiu. Pro pershi rezultaty ZNO ta plany na maibutnie [You can not measure a poppy seed with a ruler with a centimeter division. About the first results of the external evaluation and plans for the future]. Retrieved from https://zn.ua/ukr/EDUCATION/vadim-karandiy-ne-mozhnamakove-zernyatko-vimiryati-liniykoyu-z-santimetrovoyu-podilkoyu-281335_html [in Ukrainian].

Leontiev, V. G. (2002). Psihologicheskie mekhanizmy motivacii uchebnoj deyatelinosti [Psychological mechanisms of motivation of educational activity]. Novosibirsk: Novosibirskij poligrafkombinat Publ [in Russian].

Makovetska, A. S., \& Tsurul, O. A. (2015). Formuvannia motyvatsii do vyvchennia biolohii v uchniv osnovnoi shkoly [Formation of motivation to study biology in primary school students]. In Pedahohika: tradytsii ta innovatsii [Pedahohika: tradytsii ta innovatsii]: materialy II mizhnar. nauk.-prakt. konf. (pp. 55-58). Kharkiv: Helvetyka [in Ukrainian].

Moroz, I. V. (Ed.). (2006). Zahalna metodyka navchannia biolohii [General Biology Pedagogy]: navchalnyi posibnyk dlia stud. vyshchykh navch. zakladiv. Kyiv: Lybid [in Ukrainian].

Motyvatsiia do navchannia. Anketa dlia starshoklasnykiv [Motivation to learn. Questionnaire for high school students]. (2020). Retrieved

from https://docs.google.com/forms/d/e/1FAIpQLSfdMMloq_10cINhehDM4d8yV7_IxoKFTxuhH6cYLwhhoCFITw/viewform ?usp=sf_link [in Ukrainian].

Okuneva, YU. O., \& Vasil'eva, L. A. (2007). Metodika izucheniya motivacii ucheniya starsheklassnikov [Methods of studying the motivation of high school students]. Internet Education Federation Training Center. Retrieved from http://fio.novgorod.ru/projects/project2007/diagnost.htm [in Russian].

\section{ZAITSEVA I., YUSYPIVA T.}

Oles Honchar Dnipro National University (Ukraine)

\section{MIASOID H.}

Alfred Nobel University (Dnipro, Ukraine)

\section{EDUCATIONAL MOTIVATION OF STUDENTS TO STUDY BIOLOGY IN SECONDARY SCHOOL AND LYCEUM OF BIOLOGICAL PROFILE}

The article considers the issues of educational motivation, in particular the motivation to study biology in secondary and specialized public schools. The paper examines types of learning motivation: internal and external (Derbeniova, 2012), social motives to learn (Bozhovych, 2001), motivation as a personal trait (Leontiev, 2002). Issues with low involvement of high school students to take an external examination in biology were also in focus. Some scholars argue, that secondaryschools are mainly focused on maintaining external motivation in the form of tests, orders and requirements, which has a detrimental effect on internal motivation and leads to a gradual decrease in students' interest in learning (Makovetska, 2015), while specialised high school, in particular in the natural sciences, creates motivating learning environments, like innovative forms and methods of teaching, which build stronger student conscious motivation for learning and facilitate cognitive activity, which promotes the development of abilities and talents, needs and skills for self-improvement. future training (Moroz, 2006). Therefore, the purpose of the study was to conduct a comparative analysis of student motivation to study biology in secondary school and in the lyceum of biological profile.

The phenomenon of motivation and learning motivation of secondary school students and specialized medical education institutions by surveying high school students using the methods of O. Okuneva, L. Vasilieva and additional questions on motivation to study biology. According to the method by O. Okuneva, L. Vasilieva, the level of development of learning motivation, type of motivation and motivation indicator as an indicator of success and avoidance of failures were revealed, factors influencing student learning were analysed. It is established that all blocks of the motivational structure have higher scores among the respondents of the specialised institution of secondary education. The largest statistical difference was observed in students of the two institutions in block 2 , the formation of the ability to set goals. Students of the profile institution have a higher individual focus on learning, better formed internal incentives, as well as greater self-confidence and independence from other members of the group, whichhelps to choose a future profession. As a result of the survey, organizational forms of education and types of tasks that should be used in the educational process in order to strengthen the learning motivation of high school students are identified. 
Key words: biology, diagnostics, educational motivation, methods of studying motivation, secondary education institutions, surveys, questionnaires

Стаття надійшла до редакції 02.05.2021 p.

DOI: https://doi.org/10.33989/2075-146x.2021.27.247060

УДК 37.094МАКАРЕНКО

\title{
ЮЛІЯ КАРАБУТ
}

ORCID: 0000-0002-8283

Полтавський національний педагогічний університет імені В.Г. Короленка

\section{ФОРМИ БУТТЯ ПРАВА В ПЕДАГОГІЧНІЙ ТЕОРІЇ І ПРАКТИЦІ А. С. МАКАРЕНКА}

\begin{abstract}
Стаття торкається проблеми використання досвіду А. С. Макаренка у сучасній виховній практиці, зокрема, правового виховання дітей та молоді. А.С. Макаренко як педагог залишив чимало свідчень того, як неповнолітні злочинці ставали правосвідомими громадянами. 3 цих позицій форми буття права, відображені в його теоретичному та практичному спадку, становлять значний інтерес для здійснення ефективного виховного впливу на молодь.
\end{abstract}

Ключові слова: А. С. Макаренко; педагогічний досвід; неповнолітні правопорушники; право; правосвідомість; правові норми; правовідносини; правове виховання

Постановка проблеми. Теоретичний і практичний спадок А. Макаренка належить до скарбів не лише нашого народу, а $є$ надбанням усього людства. Одним із найвагоміших його аспектів $є$ повернення значної кількості дітей та молоді, що силою обставин опинилися в злочинному середовищі і самі стали його часткою, до звичайного життя на засадах законослухняності. При цьому педагог не вдавався до засобів, здатних зламати особистість, заснованих на приниженні, примусі, залякуванні, тобто виховував їх повноцінними людьми вільними у своїх життєвих виборах, що, однак, не спричиняло в них намірів повернутися до кримінального світу. Тож вивчення різних аспектів виховної системи А. С. Макаренка залишається досить затребуваним напрямом наукових досліджень, оскільки їі результативність привертає увагу фахівців і широкої громадськості вже близько 100 років.

Аналіз досліджень проблеми. Плеяда вітчизняних і зарубіжних макаренкознавців була і залишається досить обширною. Дослідниками життя і педагогічного спадку Антона Семеновича в різні часи стали I. Аносов, М. Гетьманець, Л.Гриценко, Н. Дічек, І. Зязюн, С. Карпенчук, Л.Крамущенко, І. Кривонос, В. Моргун, С. Невська, М Окса, Л. Пашко, Н. Тарасевич, А. Ткаченко, А. Фролов, Г.Хілліг, М. Ярмаченко і чимало інших відомих і менш знаних учених, а також педагогів-практиків, чия професійна доля спонукала їх до пошуку відповідей на нагальні питання у творах видатних попередників.

Водночас, не викликає заперечень факт: Макаренко був настільки багатогранним у своєму професійному і особистісному світобаченні, що скарбниця його ідей і відкриттів досі не вичерпана, особливо там, де педагогічні аспекти тісно переплелися з психологічними, соціологічними, управлінськими, юридичними та ін. Тому мета нашої статті - з'ясувати, у яких формах педагогом забезпечувалося буття права у теорії і практиці роботи 3 дитячим колективом, який водночас поєднував у собі риси і об’єкта, і суб’єкта правового виховання.

Виклад основного матеріалу дослідження. Право як явище суспільне, філософське, комунікативне тощо становить предмет обговорення впродовж багатьох тисячоліть. Різноманітні концепції права презентують його визначення, які щоразу акцентують той чи інший його аспект, характеризують окремі форми його буття, що в своїй сукупності саме й розкривають правову реальність як притаманний людській спільноті, динамічний за своїм змістом і формами функціонування спосіб регулювання відносин у соціумі.

На основі аналізу правової реальності традиційно виокремлюють низку форм буття права, що простежуються в суспільній практиці. До них відносяться:

- ідея права як основа суспільно-регуляторного задуму;

- правові норми і закони, що представляють право у знакових формах;

- правове життя, в якому право функціонує у формі взаємодії між суб'єктами.

Проте в контексті дитячого колективу, члени якого за допомогою виховання і освіти звільнялися від анархічного, кримінального за багатьма своїми ознаками світобачення, більш доречно, на наш погляд, розглядати такі форми (рівні) буття права, як правосвідомість (усвідомлення необхідності співіснувати на правових засадах); правові норми - упорядковані правила, яких кожен, хто не бажав стати поза людською 